\title{
First records of diapsid Palacrodon from the Norian, Late Triassic Chinle Formation of Arizona, and their biogeographic implications
}

\author{
Ben T. Kligman, Adam D. Marsh, and William G. Parker \\ Acta Palaeontologica Polonica 63 (1), 2018: 117-127 doi:https://doi.org/10.4202/app.00426.2017
}

Vertebrates from the Triassic Period have broadly disparate tooth shapes and dentition patterns, the result of intense morphospace experimentation following the Permo-Triassic extinction. Here, we describe fragmentary tooth-bearing jaw elements of the rare Gondwanan Middle Triassic taxon Palacrodon that represent first occurrences from the Upper Triassic Chinle Formation in northeastern Arizona. These specimens come from two notably diverse macrovertebrate and microvertebrate assemblages, the "coprolite layer" horizon in Petrified Forest National Park, and the Placerias Quarry near St. Johns, Arizona. Palacrodon is diagnosed by the presence of acrodont maxillary and dentary dentition of labiolingually-widened, bulbous teeth, which are fused to one another mesiodistally, and are pyramidal in lateral view. We agree with previous workers and refer Palacrodon to Diapsida based on the presence of a posterior jugal spur and a quadrate that has a quadratojugal foramen and a concave posterior surface. Formerly known only from the Cynognathus Assemblage Zone in southern Africa and Antarctica, the presence of Palacrodon in the Norian of North America represents a temporal range extension of at least 15 million years and represents the first tetrapod genus known to be present in the Karoo Basin, Fremouw Formation, and the Upper Triassic of the southwestern United States. Range extensions such as this suggest that some vertebrate biostratigraphic hypotheses for the Triassic may be less robust than previously believed and subject to significant sampling biases.

Key words: Diapsida, Palacrodon, microvertebrate, biostratigraphy, Triassic, Chinle Formation, North America.

Ben T. Kligman [benkligman@gmail.com], Adam D. Marsh [adam_marsh@nps.gov ], and William G. Parker [william_parker@nps.gov], Division of Science and Resource Management, 1 Park Road, \#2217, Petrified Forest National Park, Arizona 86028 USA. 
This is an open-access article distributed under the terms of the Creative Commons

Attribution License (for details please see creativecommons.org), which permits unrestricted use, distribution, and reproduction in any medium, provided the original author and source are credited.

FaF 